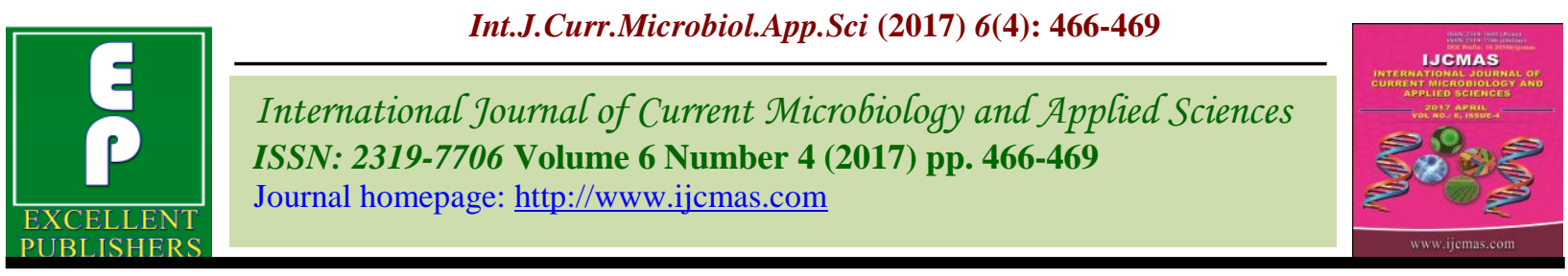

Original Research Article

https://doi.org/10.20546/ijcmas.2017.604.054

\title{
Livelihood Security of Poor Families through Pratapdhan Backyard Poultry Rearing in Kota District of Rajasthan
}

\author{
Mahendra Singh*, Mahesh Kumar Poonia, Bheru Lal Kumhar and Gitam Singh \\ Krishi Vigyan Kendra, Borkhera, Kota - 324001 and K.V.K., Tonk, Rajasthan-304022, India \\ *Corresponding author
}

\section{A B S T R A C T}

\begin{tabular}{|l|}
\hline Ke y w o r d s \\
Pratapdhan poultry, \\
Desi poultry, \\
Livelihood security, \\
Poor family. \\
\hline Article Info \\
\hline Accepted: \\
02 March 2017 \\
Available Online: \\
10 April 2017 \\
\hline \hline
\end{tabular}

The present study was conducted at Krishi Vigyan Kendra, Kota district of Rajasthan. Choma kot village was selected from the identified on the basis of maximum numbers of beneficiaries under NICRA. Ten farmers from each village were selected randomly, ten of them having Pratapdhan poultry (beneficiaries under NICRA) and rest ten having desi poultry (non-beneficiaries) were selected thus making a sample of 10 respondents. The average age of first egg laying 170 days in Pratapdhan and 185 days in local poultry, the average egg production per poultry per year was recorded 161 in Pratapdhan poultry and 56 in desi poultry. Hence, it is concluded that the performance of beneficiaries respondents (under NICRA i.e. Pratapdhan poultry) was better than non-beneficiaries respondents (under non NICRA i.e. desi poultry).

\section{Introduction}

Backyard poultry farming plays an important role in the economic upliftment of poor farmers. Stress free and harmful residue free poultry obtained from backyard poultry farming get a great scope in the availability of quality meat. Generally in rural areas farmers have been maintaining backyard poultry for income generation, home consumption, gifts and sacrifice for guests. Backyard poultry is a great need to increase the availability of protein food source in rural areas to alleviate protein malnutrition. This can be achieved by adopting poultry farming in small scale in the back yard of rural households or rearing them under intensive farm conditions in small numbers by utilizing locally available, less expensive feed and housing inputs. Backyard poultry is identified as a significant livelihood activity for many poor and landless families and particularly for women who looks for additional income. The socio economic condition of the farmers does not permit them to adopt any new technology there by resulting in low productivity and low level of income. To increase the income of such family a need was to introduce Pratapdhan breed of backyard poultry for livelihood security of poor family through conducting front line demonstration and training. Therefore, the present study was carried out on Pratapdhan backyard poultry in rural area of Kota district of Rajasthan. In the context of Indian poultry production, during the past four decades, poultry industry has transformed itself from the age-old backyard farming into a dynamic agri based industry. India is currently producing 2.75 million tones of chicken meat and 65.48 million (2.86 
million tones) of hen eggs/year. The poultry industry with the strength of 3227 million layers and 2224 million broilers employs 3.0 million persons and contributes over Rs.45, 416 crores to the Gross National Product (Prabhakaran, 2012).

Pratapdhan poultry were dual purpose and have found great acceptance and good adaptability to local conditions. The human population of India is about 1220 million in 2012 and it is predicted that another 877 million will be added to the existing human population in 2050 with the growth rate of $1.6 \%$ per year. The present per-capita availability of eggs is 54, while chicken meat consumption is $2.2 \mathrm{~kg}$ whereas the ICMR recommendation is the consumption of 180 eggs and $10.8 \mathrm{~kg}$ poultry meat per person per annum. Therefore, to bridge the gap between availability and requirement, the layer and broiler industry has to be up scaled by 5 and 10 folds, respectively.

Attractive multi colour feather pattern, as rural people like coloured birds from aesthetic point of view and better looking. Because of colour plumage birds have camouflagic characters to protect themselves from predators. Longer shank length which help in self protection from predators in backyard areas.

Good adaptability in backyard/ free-range, it has good immune competence as there is lack of availability of good quality food and drinking water, the birds have to roam into dirty surrounding in search of food. Further it has capacity to survive on low plane of nutrition (low and negligible input) and harsh climatic conditions. Produce brown shell egg and broody characteristic.

The BNR cross developed from BN cross (PB-2 $\times$ Native) $\times$ RIR at Udaipur centre was released as a dual purpose variety, Pratapdhan for rural poultry.

\section{Materials and Methods}

The study area of Choma kot village, Sultanpur block, Kota district, comes under agro climatic Zone $\mathrm{V}$ of the Rajasthan and is situated in the South eastern part of the Kota district. Under front line demonstrations the KVK was distributed 10 units of Pratapdhan poultry, each unit having 20 chicks of 6 weeks of age under National Innovation on Climate Resilient in Agriculture (NICRA in 10 Farmers of Degod blocks of Kota district). A survey was conducted on 10 beneficiaries farmers for performance evaluation of Pratapdhan poultry at different stages of growth with respect to income received from sale of eggs and meat over local poultry. Data were collected by direct interview of the beneficiaries.

\section{Results and Discussion}

Success of the Pratapdhan poultry in rural area was judged by feedback received from beneficiaries in three dimensions i.e. adoption by no beneficiaries, income generation and nutritional security. The findings on the socioeconomic impact of the transferred improved Pratapdhan breed production practices in adopted villages are presented and discussed in terms of skill, socio-economic indicators and status of family's assets. Practice wise skill improvement in recommended/ demonstrated improved poultry production practices (Table 1).

\section{Adoption by non-beneficiaries}

The large number of families in the rural area are belongs to landless labourers, marginal and small farmers who depend on daily casual works round the year for their livelihood. Poultry keeping is the age old practice in rural areas, but drawback is their low productivity and the less return from each bird. The major feed ingredients like kitchen waste, green 
grasses, earthworms, and insects are required for backyard poultry farming which is available in abundance in rural areas. These waste materials can be converted them into highly balanced and delicious nutritive diet of egg and chicken meat. Backyard poultry farming will help enhancing the nutritional and economic status of rural people. The egg laying capacity of Pratapdhan poultry was recorded $74.19 \%$ higher as compared to desi poultry thus why the numbers of farm families have purchased eggs from beneficiaries by paying Rs 10 per egg and hatched with their own local hen. The second generation had started laying eggs after 25 weeks of hatching.

\section{Income generation}

Backyard poultry rearing become income source for the family in the study area. Net profit per poultry Rs. 275.50 and benefit cost ratio is $1: 2.45$ for rearing of one unit of Pratapdhan poultry. These results get support from earlier observations of Shetter and Jadhave (1999) and Yadav and Khan (2011). Dhapu Bai of Choma kot village also participated in this training and after training she provided a Demonstration unit of 20 chicks.

Presently she has 60 birds units. She generating sufficient amount i.e. 2500-3500 per month from sale of eggs and birds. She is acting as a role model for other farmers of this area. Backyard poultry farming is a main source of subsidiary income and gainful employment to land less labour throughout the year.

Table.1 Analysis of production at the age 6 months

\begin{tabular}{|l|l|l|l|l|l|}
\hline S. No. & Group & \multicolumn{2}{|l|}{ Performance of Pratapdhan Poultry } & \multicolumn{2}{l|}{ Performance of Desi Poultry } \\
\cline { 3 - 6 } & & $\begin{array}{l}\text { Live weight Overall } \\
\text { Average (kg) }\end{array}$ & $\begin{array}{l}\text { Egg production Overall } \\
\text { Average (monthly) }\end{array}$ & $\begin{array}{l}\text { Live weight Overall } \\
\text { Average (kg) }\end{array}$ & $\begin{array}{l}\text { Egg production Overall } \\
\text { Average (monthly) }\end{array}$ \\
\hline $\mathbf{1 .}$ & I & $3.66 \pm 0.140(20)$ & $18.65 \pm 02(20)$ & $2.06 \pm 0.140(20)$ & $7.83 \pm 02(20)$ \\
\hline $\mathbf{2 .}$ & II & $3.36 \pm 0.189(20)$ & $17.98 \pm 02(20)$ & $2.03 \pm 0.189(20)$ & $6.33 \pm 02(20)$ \\
\hline $\mathbf{3 .}$ & III & $3.23 \pm 0.171(20)$ & $19.19 \pm 02(20)$ & $2.01 \pm 0.171(20)$ & $6.00 \pm 02(20)$ \\
\hline $\mathbf{4 .}$ & IV & $3.76 \pm 0.134(20)$ & $15.12 \pm 02(20)$ & $1.94 \pm 0.134(20)$ & $6.28 \pm 02(20)$ \\
\hline $\mathbf{5 .}$ & V & $3.87 \pm 0.157(20)$ & $18.47 \pm 02(20)$ & $1.92 \pm 0.157(20)$ & $5.83 \pm 02(20)$ \\
\hline $\mathbf{6 .}$ & VI & $3.48 \pm 0.134(20)$ & $16.93 \pm 02(20)$ & $1.59 \pm 0.134(20)$ & $6.83 \pm 02(20)$ \\
\hline $\mathbf{7 .}$ & VII & $3.22 \pm 0.120(20)$ & $12.83 \pm 02(20)$ & $1.27 \pm 0.189(20)$ & $7.83 \pm 02(20)$ \\
\hline $\mathbf{8 .}$ & VIII & $3.43 \pm 0.113(20)$ & $14.33 \pm 02(20)$ & $1.87 \pm 0.189(20)$ & $6.33 \pm 02(20)$ \\
\hline $\mathbf{9 .}$ & IX & $3.69 \pm 0.148(20)$ & $11.10 \pm 02(20)$ & $1.92 \pm 0.189(20)$ & $6.00 \pm 02(20)$ \\
\hline $\mathbf{1 0}$. & X & $3.91 \pm 0.153(20)$ & $13.37 \pm 02(20)$ & $1.87 \pm 0.189(20)$ & $5.11 \pm 02(20)$ \\
\hline
\end{tabular}

Fig.1 Various stages of trial
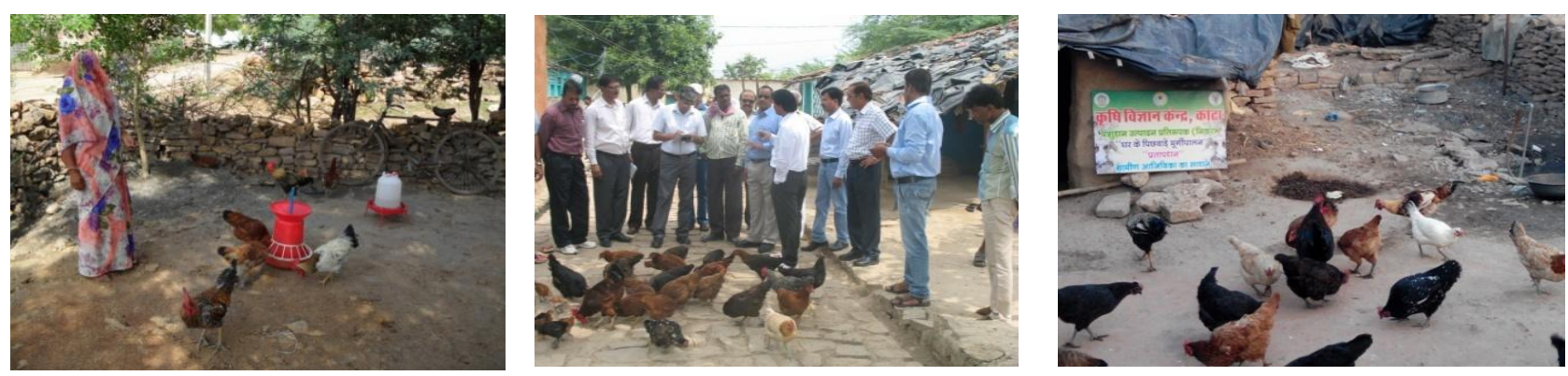


\section{Nutritional security}

The rural poor families rearing Pratapdhan poultry (provided under NICRA) as backyard poultry experienced on economic upliftment along with an alleviation of nutritional status due to higher egg production $(74.19 \%)$ and weight gain of males $(52.38 \%)$ as compared to local poultry. The data revealed that the annual average egg production of Pratapdhan poultry in comparison to desi poultries were 161 and 56, respectively. The results of present study are similar to the work of Mandaland Gautam (2003), Singh et al., (2003) and Yandi and Khan (2011). Average weight gain $(\mathrm{kg})$ of adult male and female of Pratapdhan poultry was recorded 3.20 and 2.10 while, for desi poultry 2.10 and 1.35 , respectively. The similar trends in gain in body weight of Pratapdhan over local poultry were reported by Yadav and Khan (2011).

\section{Institutional intervention}

Continuous efforts of KVK for backyard poultry farming in Kota district played a pivotal role in the nutritional security as well as regular income generation of landless labour and marginal farmers in rural areas of the Kota District. The successful interventions of NICRA backyard poultry was scaled by Kota District administration of ATMA.
Concluded on the basis of findings of this study it can be that Pratapdhan poultry in backyards of poor family should be reared in order to secure their livelihood and to overcome with malnutrition problem.

\section{References}

Mandal, M.K. and Gautam, U.B. 2003. Status of backyard poultry farming in Pura Tehsil of Jammu District. $J$. Interacademicia, 7: 491-493.

Prabhakaran, R. 2012. Proc. XXIX National Symposium of IPSACON, 2012 held at PDP, Hyderabad during 5-7 ${ }^{\text {th }}$ December 2012.

Shettar, V.B. and Jadhav, N.V. 1999. Economic evaluation of small scale broiler farming. Indian Vet. J., 76: 663665.

Singh, D.P., Johri, T.S., Narayan, R., Singh, D. and Saran, S. 2003. Implemented integrated approach for traditional village poultry production. Bhartiya Krishi Anusandhan Patrika, 18: 93-101.

Yadav, C.M. and Khan, P.M. 2011. Pratapdhan backyard poultryrearing - a tool to fight poverty in rural area of Bhilwara district in Rajasthan. $J$. Progressive Agri., 2: 65-66.

\section{How to cite this article:}

Mahendra Singh, Mahesh Kumar Poonia, Bheru Lal Kumhar and Gitam Singh. 2017. Livelihood Security of Poor Families through Pratapdhan Backyard Poultry Rearing in Kota District of Rajasthan. Int.J.Curr.Microbiol.App.Sci. 6(4): 466-469. doi: https://doi.org/10.20546/ijcmas.2017.604.054 